Adam Falewicz, PhD*, https:/ / orcid.org/0000-0002-0412-7602

Professor Stanisława Steuden**, https:/ / orcid.org/0000-0003-0078-5613

*Institute of Psychology

Faculty of Social Sciences

University of Szczecin

**Institute of Psychology

University of Economics

and Human Sciences in Warsaw

\title{
Typology of people in middle and late adulthood based on the profile of coping with everyday life events
}

\section{Typologia osób w średniej i późnej dorosłości pod względem profilu radzenia sobie $\mathrm{z}$ codziennymi wydarzeniami ${ }^{1}$}

https://doi.org/10.34766/fetr.v48i4.989

\begin{abstract}
Introduction. The purpose of this study was to construct a typology of the proactive coping profiles of individuals in middle and late adulthood. The conceptual layer refers to the theory of proactive coping as defined by Ralf Schwarzer and Steffen Taubert. It means such an approach to everyday life in which problems are treated as a challenge rather than as a great unknown that limits to only reactive responses to emerging difficulties. An attempt was also made to compare the obtained subtypes in terms of wisdom and resilience. According to Ardelt's research, wisdom, understood as a composite of cognitive, reflective, and emotional components, may be a resource characterizing adults who use mature coping strategies, particularly proactive coping. Building resilience in people helps to prevent stress, hence it can be considered as a resource important in proactive coping. Method. A group of 166 people in middle $(\mathrm{N}=80)$ and late adulthood $(\mathrm{N}=86)$ was surveyed. The Proactive Coping Inventory (Polish Adaptation) by Sęk, Pasikowski, Taubert, Greenglass and Schwarzer, ThreeDimensional Wisdom Scale (3D-WS) by Ardelt, adapted by Steuden, Brudek and Izdebski and Resilience Measurement Scale (SPP-25) by Oginska-Bulik and Juczynski were used in the study. Results. Four coping types were obtained: runaway, proactive, autonomous and support-seekers. Individuals belonging to particular profiles of coping differed significantly in the level of wisdom and resilience. Conclusions. The study showed that in a group of people in middle and late adulthood it is possible to distinguish consistent profiles of using coping strategies, which differ in the degree of proactivity. Additionally, wisdom and resilience were shown to characterize individuals with a more proactive, goal-oriented structure of coping strategies.
\end{abstract}

Keywords: proactive coping; wisdom; resilience; middle adulthood; late adulthood

Abstrakt: Wstęp. Celem badań było skonstruowanie typologii profilu radzenia sobie z codziennymi wydarzeniami w grupie osób w średniej i późnej dorosłości. W warstwie koncepcyjnej odwołano się do teorii proaktywnego radzenia sobie w ujęciu Ralfa Schwarzera i Steffena Tauberta. Oznacza ono

\footnotetext{
${ }^{1}$ Artykuł w języku polskim dostępny jest na stronie:

https://www.stowarzyszeniefidesetratio.pl/Presentations0/2021-4Falew2.pdf
} 
takie ujmowanie codzienności, w którym problemy traktowane są jako wyzwanie, nie zaś jako wielka niewiadoma, która ogranicza do wyłącznie reaktywnych odpowiedzi na pojawiające się trudności. Podjęto także próbę porównania uzyskanych podtypów pod względem mądrości i prężności. Zgodnie z badaniami Ardelt, mądrość, rozumiana jako złożenie komponentu poznawczego, refleksyjnego i emocjonalnego, może być zasobem charakteryzującym osoby dorosłe, które stosują dojrzałe strategie zaradcze, a w szczególności proaktywne radzenie sobie. Budowanie w ludziach prężności pomaga zapobiegać stresowi, stąd można ją traktować jako zasób istotny w proaktywnym radzeniu sobie. Metoda. Badaniu poddano grupę 166 osób w średniej $(\mathrm{N}=80)$ i późnej dorosłości (N=86). W badaniach wykorzystano Kwestionariusz Reakcji na Codzienne Wydarzenia (The Proactive Coping Inventory - Polish Adaptation) Sęk, Pasikowskiego, Tauberta, Greenglass i Schwarzera, Trzywymiarową Skalą Mądrości Życiowej (Three-Dimensional Wisdom Scale: 3D-WS) autorstwa Ardelt, w adaptacji Steuden, Brudka i Izdebskiego oraz Skalę Pomiaru Prężności (SPP-25), autorstwa Ogińskiej-Bulik i Juczyńskiego. Wyniki. Uzyskano cztery typy radzenia sobie: ucieczkowy, proaktywny, autonomiczny i poszukujący wsparcia. Osoby przynależące do poszczególnych profili radzenia sobie istotnie różniły się poziomem mądrości i prężności. Wnioski. Badanie pokazało, że w grupie osób w średniej i późnej dorosłości można wyodrębnić spójne profile stosowania strategii zaradczych, które różnią się stopniem proaktywności. Dodatkowo wykazano, iż mądrość i prężność charakteryzuje osoby mające bardziej proaktywną, ukierunkowaną na stawianie sobie celów strukturę strategii zaradczych.

Słowa kluczowe: proaktywne radzenie sobie; mądrość; prężność; średnia dorosłość; późna dorosłość

\section{Introduction}

As existing research shows, there are clear changes in coping styles over the life course (Aldwin, Yancura, \& Lee, 2021, p. 279; Diehl, Chui, Hay, Lumley, Grühn, \& LabouvieVief, 2014). The direction of these changes mostly shows a development from less adaptive and defensive strategies (in adolescence) to more adaptive strategies (in middle adulthood). It appears, however, that this direction is reversed in late adulthood, which places specific demands on older people in terms of shaping their resources necessary for adaptive coping. This is because the development of coping strategies and more mature defense mechanisms is associated with more complex cognitive processes, such as memory or decision-making ability, as well as higher levels of self-reflection and the ability to plan behavior. Brennan and his team (2012) found a normative pattern in a prospective study, which shows that there is a decline in the use of both active and avoidant coping methods over time. However, they note that this trend may be dependent on how the older person assesses the stressor, the nature of the problem, and the personal and social resources they possess, at the threshold of late adulthood. Aldwin, Choun, and Spiro (2017) found that although coping efforts gradually decrease as people move from middle age to around 65 years of age (before increasing again at the end of life), coping effectiveness remains similar. Individuals in middle as well as late adulthood experience stressful events; however, older individuals perceive them to be less unpleasant (Neubauer, Smyth, \& Sliwinski, 2019, p. 15). Research by Chen, Peng, Xu, \& O'Brien (2018) showed that individuals in late adulthood use problem-focused coping to a lesser extent compared to young adults. 
However, despite the evidence of changing coping styles over the life course, it cannot be claimed that this is a clear indication that a decrease or increase in coping resources with age. A study of the coping resources of people in middle (45-64), late (65-74) and very late (over 75) adulthood failed to show significant differences in the effectiveness of coping activities between groups (Hamarat, Thompson, Steele, Matheny, Simons, 2002, p. 364). It therefore appears that coping resources, such as personality traits, remain relatively constant over the life course. In view of this, late adulthood may be a time of prosperity and resilience. The coping of people in middle and late adulthood therefore appears to differ precisely because of the different resources available at any given time.

Changes in health and fitness in late adulthood lead to greater vulnerability toward stress. This has an impact on the choice of coping strategies, as the reduced effectiveness of one's own coping tends to make one turn to social resources. However, it is important to note the risk of a demanding attitude on the part of older people, which may relieve them of the responsibility to be proactive themselves. The first line of support is the immediate community, i.e. marriage. The extent to which older people reach out for help from others depends on their state of health and the quality of their psychosocial functioning. Coping resources are therefore wisdom and life experience. The differences between people in middle and late adulthood in the use of specific coping strategies are also highlighted. Individuals in middle adulthood are more likely to use active, interpersonal and problemoriented strategies (e.g. confrontation, seeking social support), while they are less likely to use passive, emotion-focused or intrapersonal strategies (such as taking responsibility, positive reappraisal). These differences may, however, be apparent and result more from poor recognition of the specific nature of stress in a given period, which is not always adequately taken into account in research (Brzezińska, 2011, p. 121).

The coping behaviors undertaken by seniors often tend to adopt the form of proactive strategies (Blanco-Molina, Pinazo-Hernandis, Montoro-Rodriguez, \& Tomas, 2021). These are coping styles that are particularly relevant in dealing with problems that could potentially occur in later old age, such as loss of health, the danger of losing livelihoods, or the inevitable loss of loved ones (Steuden, 2017, p. 87). Elderly people, by building a network of interpersonal relationships, and improving their material situation or housing conditions, build the resources needed to optimize their functioning in the face of the limitations imposed by age (Brzezinska, 2011, p. 122; cf. Ribeiro, Borges, Araújo \& Souza, 2017).

According to Steuden (2017, p. 216), older people faced with an ego-despair integration crisis may reach for the strategy of reinterpreting their lives by reviewing them. This builds the individual's reflexivity and reduces subjectivity in approaching the world. It reduces egocentrism and thus enables one to accept their present status and to reconcile with the past. Coping with the difficulties of life in late adulthood is also achieved through 
educational (universities of the third age), cultural and social activities. A significant role is also played by religious coping (Vitorino, Low \& Vianna, 2016).

\section{Proactive coping in the concept of Ralf Schwarzer and Steffen Taubert}

A number of psychological theories on coping have evolved to detail as precisely as possible the potential spheres involved in coping processes (Noone, 2017). Ralf Schwarzer and Steffen Taubert (2002) noted that the temporal perspective is vital in coping. Threats to an individual's well-being, in their view, are not only embedded in the past or present, but also in the perspective of future difficulties and challenges. In developing the concept of proactive coping, they referred to the distinction made by Beehr and McGrath (1996, p. 67), who identified five types of coping behavior embedded in a temporal perspective: 1) preventive coping; 2) anticipatory coping; 3) dynamic coping; 4) reactive coping; and 5) residual coping. Nevertheless, Schwarzer and Taubert (2002) considered that this classification, although providing a forward-looking perspective, focused on the reaction to an event. In this regard, they introduced the concept of proactive coping, which is distinctly prospectively focused. According to the theory they proposed, the new type of coping activity was placed alongside reactive, anticipatory and preventive coping.

Reactive coping can be defined as the effort an individual makes to cope with a stressful event that has already occurred. Because this type of coping deals with a stressor that has already occurred, efforts are directed toward compensating for the loss or mitigating the damage (Gamrowska, Galkowska-Bachanek, 2014, p. 506).

Anticipatory coping refers to activity directed toward an imminent, upcoming threat. A person confronts a critical event that he or she is certain will occur in the near future. In anticipatory coping, there is a risk that a future event will cause harm or loss, which prompts the person to undertake management of the perceived risk. Cognitive appraisal of the situation indicates that the danger is close and threatening. The role of coping is to deal with the problem at the moment of perceived difficulty by responding appropriately: increasing one's own effort, seeking help, or engaging other available resources. In this type of coping, the involvement of personal resources to prevent or face the source of stress is taken into account (Gamrowska, Steuden, 2014, p. 124).

Preventive coping means building up general resilience resources that reduce the severity of the consequences of stress (if they were to occur) and reduce the likelihood of stressful events. Through a preventive coping strategy, a person faces a critical moment that may or may not occur in the distant future. Managing the risk of a stressor in this case means dealing with various unknown risks in the distant future (Reuter, Schwarzer, 2015, p. 505).

Proactive coping consists of efforts directed at building up general resources that relate to personal goal-setting and personal development. The idea of proactive coping takes 
into account that individuals vary greatly in the resources they use in stressful situations. These may include specific coping strategies, personality traits (such as self-efficacy, sense of control, self-esteem) and social support. More favorable and diverse personal resources enable individuals to cope with stress more effectively (Greenglass, Fiksenbaum, 2009, p. 30). Schwarzer and Taubert (2002) referred in their concept directly to Hobfoll's theory of resource behavior (cf. Bernat, Krzyszkowska, 2017; Chwaszcz, Bartczuk, Niewiadomska, Hobfoll \& Palacz-Chrisidis, 2020). In his view, people work to acquire resources they do not have, maintain those they do have, protect resources when they are threatened, and support resources so that they can be used to their best advantage. In this approach, stress arises from circumstances where resources are threatened or have already been lost. Proactive coping, on the other hand, means having a perspective in which people see risks, demands and opportunities in the distant future, but do not evaluate them in terms of loss, harm or threat. The way difficult situations are perceived is radically different because the individual sees them as challenges. Coping becomes goal management rather than risk management. This means that the individual is not reactive but becomes proactive in the sense that they take constructive action and create circumstances that foster personal growth. Preventive and proactive coping are sometimes outwardly similar and can manifest themselves in behaviors such as, for example, skill development, resource gathering and long-term planning. The motivation for these activities differs, however, as the former is driven by an assessment of the situation as a threat and the latter as an opportunity and challenge. As Schwarzer (2000; cf. Zhou, Gan, Knoll, \& Schwarzer, 2013) notes, in preventive coping this difference can be seen in higher levels of worry, with relatively lower levels in proactive behaviors.

The process of anticipation of potential stressors combined with action to pre-empt and prevent their effects can also display features of proactivity. The extent to which individuals balance, eliminate, reduce or modify impending stressful events reveals that proactive behavior can eliminate many sources of stress. As Aspinwall and Taylor (1997) note, the skills that are necessary to engage in proactive behavior are the ability to plan and set life goals, organizational skills and the ability to make mental simulations of future events.

Proactive coping aims at building a set of general resources that facilitate development toward goals and personal improvement; it connects with a vision of potential future events (demands, opportunities, challenges), but does not value them negatively, and involves autonomously and independently setting goals, seeking challenges and engaging voluntarily in stressful transactions (Reuter, Schwarzer, 2015; Schwarzer, Taubert 2002).

An important characteristic of proactive coping is the use of practical, informational and emotional resources that other people can provide (Greenglass, 2002). 
The concept of proactive coping has been operationalized by Greenglass, Schwarzer, Jakubiec, Fiksenbaum, and Taubert (2014) in the form of The Proactive Coping Inventory (PCI), which has the following subscales:

1) proactive coping - combines the ability to autonomously set goals with goaldirected cognitive and behavioral activities;

2) reflective coping - describes the mental simulations and reflections on the potential possibilities of a behavior and its effectiveness. Reflective coping consists of behaviors such as generating possible solutions (brainstorming), analysing problems and resources, and generating hypothetical action plans;

3) strategic planning - focuses on the processes of constructing a schedule of goaloriented activities in which larger tasks are broken down into smaller, manageable activities;

4) preventive coping - means anticipating potential stressors and starting to prepare before the threat fully develops. Preventive coping targets potential threats that the individual perceives on the basis of their past experiences and knowledge;

5) instrumental support seeking - means asking for help (in the form of advice, information and feedback) from people in the immediate environment, forming a social support network;

6) emotional support seeking - means a way of coping in which a person regulates emotional distress that is experienced at a given moment by confiding in others, arousing empathy and looking for the company of acquaintances and friends. The person using this strategy copes with the emotions associated with the stress experienced by seeking help from significant others.

7) avoidant coping - describes activities that mean postponing taking action in the context of an upcoming difficult situation. (Brzezinska, 2011, p. 87; cf.; Gamrowska, Galkowska-Bachanek, 2014; Greenglass, 2002).

This scale will be presented in more detail in the methodological part of the article.

\section{Aim of the study}

The aim of the research reported in this article was to construct a typology of the proactive coping profile of individuals in middle and late adulthood. Due to contradictory data on age-specific coping, an exploratory approach was adopted in the model of our study. Additionally, an attempt was made to characterize the obtained subtypes in terms of the level of selected personality traits - wisdom and resilience - which are documented in the literature as predictors of successful coping (Li, Miller, 2017).

Individuals who are endowed with wisdom, according to Yang (2008, p. 65), achieve personal goals and fulfill their "life mission" consistent with their ideal life vision, and wisdom has proven to be an even better predictor of life satisfaction than objective life 
conditions. Wisdom allows older people to transcend their own limitations and thus better cope with everyday difficulties (Aldwin, Igarashi, Levenson, 2019; Aldwin, Levenson, 2019). Ardelt (2003, p. 277), referring to the research of Clayton and Birren (1980), defines wisdom as a combination of cognitive, reflective and affective dimensions (Ardelt, Pridgen, NutterPridgen, 2018). In her research, she has found that wise people are exceptionally mature, integrated, satisfied with their lives, able to make decisions about difficult and uncertain life issues, and able to cope with the crises and obstacles they experience (Ardelt, 2005; Ardelt, 2016; Ardelt, Jeste, 2018). The literature on personal resources highlights the role of resilience as an important factor accompanying successful coping with stress (Campbell-Sills, FelcynKoczewska, Ogińska-Bulik, 2011，s. 522; Chanduszko-Salska, Ogińska-Bulik, 2011; Fontes, Neri, 2015; Morano, 2010; Newman, 2005; Ogińska-Bulik, 2009, 2011; Ogińska-Bulik, Juczyński, 2008; Wu, Yu, Wu, Wan, Wang, Lu, 2020). The mechanism of resilience's impact is both direct and mediated through fostering the development of positive emotions that allow one to evaluate a stressful situation more favorably, expand the cognitively available repertoire of ways to respond, and enable one to consider it as a challenge (cf. Fritzson, Lieberman, Tugade, 2017; Tugade, Devlin, Fredrickson, 2014). Research in recent years has shown that resilience is closely associated with successful aging, reduced risk of disease, and better physical and mental functioning (Jeste et al., 2013; MacLeod, Musich, Hawkins, Alsgaard, \& Wicker, 2016). Resilience can be understood as an approach to stress management that allows a person to perceive a threatening situation as a challenge and to engage in order to overcome difficulties (Gulbrandsen, 2016).

\section{Method}

\subsection{Sample}

The study included 168 subjects, and the results of 166 subjects, consisting of 129 women and 37 men, were eligible for analysis ( 2 subjects who did not complete a significant part of the 3D-WS questionnaire were eliminated). All subjects were classified by age into two groups - adults in middle and late adulthood. The sampling was not randomized, however, taking into account the correlative nature of the study and the fact that the sample was drawn from different backgrounds, it can be assumed that the effect of the group selection method was minimal. The research was conducted mainly in Western and Central Pomerania, as well as partly in the Lublin region. The group of people in middle adulthood $(\mathrm{N}=80)$ included people aged $35-60$ years $(\mathrm{M}=47.4 ; \mathrm{SD}=8.4)$ and the late adulthood group $(\mathrm{N}=86)$ included people in the 61-81 age range $(\mathrm{M}=67.5 ; \mathrm{SD}=5.1)$. Among them, there were 70 women and 16 men. A large proportion of the participants in the study group was represented by students of the University of the Third Age in Krasnystaw. The table below shows the detailed characteristics of the study group: 
Table 1. Description of the study group

\begin{tabular}{|c|c|c|c|c|c|c|}
\hline \multirow{2}{*}{ Variables } & \multicolumn{2}{|c|}{ Total } & \multicolumn{2}{|c|}{$\begin{array}{l}\text { People in middle } \\
\text { adulthood }\end{array}$} & \multicolumn{2}{|c|}{$\begin{array}{l}\text { People in late } \\
\text { adulthood }\end{array}$} \\
\hline & $\mathrm{N}$ & $\%$ & $\mathrm{~N}$ & $\%$ & $\mathrm{~N}$ & $\%$ \\
\hline \multicolumn{7}{|c|}{ Gender } \\
\hline women & 129 & 77.7 & 59 & 73.8 & 70 & 81.4 \\
\hline men & 37 & 22.3 & 21 & 26.3 & 16 & 18.6 \\
\hline total & 166 & 100 & 80 & 100 & 86 & 100 \\
\hline \multicolumn{7}{|c|}{ Residence } \\
\hline village & 58 & 34.9 & 45 & 56.3 & 13 & 15.1 \\
\hline city up to 25,000 inhabitants & 68 & 41 & 13 & 16.3 & 55 & 64.0 \\
\hline city from 25 to 100,000 inhabitants & 34 & 20.5 & 17 & 21.3 & 17 & 19.8 \\
\hline $\begin{array}{l}\text { city with more than } 100,000 \\
\text { inhabitants }\end{array}$ & 6 & 3.6 & 5 & 6.3 & 1 & 1.2 \\
\hline \multicolumn{7}{|c|}{ Professional activity } \\
\hline working & 70 & 42.2 & 68 & 85 & 2 & 2.3 \\
\hline unemployed & 2 & 1.2 & 2 & 2.5 & 0 & 0 \\
\hline annuity & 12 & 7.2 & 4 & 5 & 8 & 9.3 \\
\hline pensioner & 82 & 49.4 & 6 & 7.5 & 76 & 88.4 \\
\hline \multicolumn{7}{|c|}{ Education } \\
\hline primary school & 6 & 3.6 & 2 & 2.5 & 4 & 4.7 \\
\hline occupational & 15 & 9 & 8 & 10 & 7 & 8.1 \\
\hline secondary school & 67 & 40.4 & 23 & 28.8 & 44 & 51.2 \\
\hline higher education & 78 & 47 & 47 & 58.8 & 31 & 36 \\
\hline \multicolumn{7}{|c|}{ Assessment of the material situation } \\
\hline very good & 6 & 3.6 & 6 & 7.5 & 0 & 0 \\
\hline good & 66 & 39.8 & 38 & 47.5 & 28 & 32.6 \\
\hline average & 89 & 53.6 & 34 & 42.5 & 55 & 64 \\
\hline bad & 5 & 3 & 2 & 2.5 & 3 & 3.5 \\
\hline \multicolumn{7}{|c|}{ Marital status } \\
\hline matrimony & 104 & 62.7 & 53 & 66.3 & 51 & 59.3 \\
\hline cohabitation & 4 & 2.4 & 4 & 5 & 0 & 0 \\
\hline widow/widower & 22 & 13.3 & 2 & 2.5 & 20 & 23.3 \\
\hline divorced & 9 & 5.4 & 3 & 3.8 & 6 & 7 \\
\hline single & 27 & 16.3 & 18 & 22.5 & 9 & 10.5 \\
\hline \multicolumn{7}{|c|}{ Assessment of general health status } \\
\hline very good & 10 & 6 & 10 & 12.5 & 0 & 0 \\
\hline good & 70 & 42.2 & 44 & 55 & 26 & 30.2 \\
\hline average & 80 & 48.2 & 26 & 32.5 & 54 & 62.8 \\
\hline bad & 6 & 3.6 & 0 & 0 & 6 & 7 \\
\hline
\end{tabular}




\subsection{Procedure}

The procedure to be followed by the respondents in this study involved the completion of a set of questionnaires. The study was part of a wider project involving the investigation of various existential and religious variables and their role in how people in middle and late adulthood cope.

The research used: the Three-Dimensional Wisdom Scale (3D-WS) by Ardelt (2003), adapted by Steuden, Brudek and Izdebski (2016); the Resilience Measurement Scale (SPP-25), by Oginska-Bulik and Juczynski (2008); and the Proactive Coping Inventory (PCI), adapted by Sęk, Pasikowski, Taubert, Greenglass and Schwarzer (2014). For the final computations of the 3D-WS questionnaire results, factor analysis based on Polish studies was used, which will be discussed further when describing the individual scales.

A cluster analysis using the k-means method was performed to identify individuals differentiated by their way (type) of coping with everyday events. To compare the obtained types in terms of the level of wisdom and resilience, one-way analysis of variance was used. IBM SPSS Statistics version 25 was applied for the purpose of the analyses.

\subsection{Research tools}

The 3D-WS (Three-Dimensional Wisdom Scale) by Ardelt (2003, cf. Thomas, Bangen, Ardelt, Jeste, 2017) adapted by Steuden, Brudek and Izdebski (2016) is used to measure wisdom. This scale provides a global score describing wisdom and also allows for the assessment of its three dimensions: cognitive, reflective and affective/compassionate.

In the adaptation of the 3D-WS, standards for the translation of psychological tests were used (see Drwal, 1995). The experimental version of the 3D-WS was verified on the basis of studies of 475 people across Poland. On this basis, analyses of the psychometric properties of the items and subscales as well as the accuracy and reliability indices were conducted. The authors of the adaptation used confirmatory factor analysis (CFA) with item clustering procedures. The analyses confirmed the unidimensionality of the cognitive and affective factors. The reflective component did not meet this criterion, so by means of content analysis of the items, two aspects of the reflective dimension of wisdom were distinguished self-awareness and empathic. The fit indices of the model showed that it fits the data sufficiently $(\mathrm{CMIN} / \mathrm{df}=2.708 ; \mathrm{RMSEA}=0.071 ; \mathrm{GFI}=0.920 ; \mathrm{CFI}=0.893$; $\mathrm{TLI}=0.866)$. This provides evidence in favor of the four-dimensional nature of the studied construct. The reliability of the entire scale, measured by Cronbach's a was 0.86 , while in the subscales, for the cognitive dimension - 0.77; affective -0.64 ; self-awareness -0.73 ; empathic -0.72 .

The 3D-WS scale consists of 39 statements which are rated on a 5 -point scale, where the respondents select the following answers: yes; rather yes; both yes and no; rather no; no. The items of the questionnaire are grouped in two parts (the first contains 15 items, the second - 24). In the final version of the Polish 3D-WS scale, within the individual 
dimensions, there were: for the cognitive dimension - 14 items (e.g. "I try to anticipate and avoid situations where there is a likely chance I will have to think in depth about something"); for the affective dimension - 13 items (e.g., "I am annoyed by unhappy people who just feel sorry for themselves"); for the self-awareness dimension - 7 items (e.g., "I would feel much better if my present circumstances changed"); for the empathic dimension - 5 items (e.g., "I try to look at everybody's side of a disagreement before I make a decision"). Scores are calculated according to a key, including reversed items. The overall wisdom score is obtained by calculating the average of all four wisdom dimensions - this is the average of the four averages.

To measure resilience, we used the self-report Resilience Measurement Scale (SPP-25) by Oginska-Bulik and Juczynski (2008). Resilience measured by this scale is treated as "a personality trait, important in the process of coping effectively with both traumatic events and everyday stress". (Ogińska-Bulik, Juczyński 2008, p. 44). The scale consists of 25 statements that address various personality characteristics. In addition to the total score, the SPP-25 examines 5 factors:

1. Persistence and determination in action.

2. Openness to new experiences and a sense of humour.

3. Personal competence to cope and tolerance of negative emotions.

4. Tolerance of failure and treating life as a challenge.

5. Optimistic attitude toward life and ability to self-mobilize in difficult situations.

The respondents completed the assessment on a 5-point Likert scale (where 0 means "definitely not", 1 - "rather not"; 2 - "neither yes nor no/difficult to say"; 3 - "rather yes"; 4 - "definitely yes"). The psychometric properties of the SPP-25 scale indicate its high reliability (Cronbach's a obtained in standardization studies at the level of 0.89), stability tested by the test-retest method after four weeks was 0.85 . This is also an important premise for the recognition of the trait of resilience as a relatively stable personality characteristic. The trait of resilience examined by the SPP-25 scale in the research of the authors correlated positively with, among others, extraversion and conscientiousness (examined by NEO-FFI), emotional intelligence (INTE) and adaptive coping strategies: active coping, planning, positive reevaluation (examined by the mini-COPE questionnaire). The total score can be presented on a standard ten scale and referred to the norms proposed by the authors (Ogińska-Bulik, Juczyński 2008, p. 53). However, the researcher decided on a different criterion for distinguishing high and low scores, which will be explained in the section on analysis of the results.

Coping strategies were examined with the Reactions to Everyday Events Questionnaire PCI (Proactive Coping Inventory - Polish Adaptation), by Sęk, Pasikowski, Taubert, Greenglass and Schwarzer (2002). It is used to examine proactive coping with stress. 
The respondent was asked to address 55 statements by selecting an answer from 4 possibilities - "never", "rarely", "often" or "always".

The questionnaire consists of seven scales. The reliabilities obtained by the authors of the scale during the Polish adaptation, measured by Cronbach's a, are given in brackets.

1) The Proactive Coping Scale -14 items $(\alpha=0.87)$

2) The Reflective Coping Scale -11 items $(a=0.86)$

3) Strategic planning -4 items $(\alpha=0.74)$

4) Preventive coping - 10 items $(\alpha=0.79)$

5) Instrumental Support Seeking -8 items $(\alpha=0.81)$

6) Emotional Support Seeking - 5 items $(\alpha=0.72)$

7) Avoidance Coping - 3 items ( $a=0.67)$

It is notable that the reliabilities obtained in the Polish adaptation of the questionnaire are similar to the international samples, which shows both its correctness and cross-cultural consistency (Pasikowski et al., 2002). There are intercorrelations between the scales, which indicates that the individual dimensions are not independent from each other. Importantly, there is no correlation between proactive and avoidant coping, which justifies placing the two strategies in opposition. There was also no correlation between proactive coping and instrumental support seeking. With regard to correlations with other tools, with the exception of avoidant coping, all of the strategies examined correlated negatively with the Beck Depression Inventory score. Further, a positive correlation was noted between the PCI scales (apart from avoidant coping) and the Subjective Health Profile scale by Sęk. Proactive coping showed the highest correlation (0.58).

\section{Results of the study}

The following table shows the results obtained by the respondents in each group in the PCI questionnaire, which examines ways of coping with stress in everyday life situations. The table below also compares the mean scores obtained in the two groups.

Table 2. Comparison of mean scores on the PCI questionnaire between the middle (MA) and late adulthood (LA) groups

\begin{tabular}{|l|c|c|c|c|c|c|}
\hline \multirow{2}{*}{\multicolumn{1}{|c|}{ PCI scales }} & \multicolumn{2}{|c|}{$\mathrm{MA}(\mathrm{N}=80)$} & \multicolumn{2}{c|}{ LA (N=86) } & \multirow{2}{*}{$\mathrm{t}$} & \multirow{2}{*}{$\mathrm{p}$} \\
\cline { 2 - 6 } & $\mathrm{M}$ & $\mathrm{SD}$ & $\mathrm{M}$ & $\mathrm{SD}$ & & \\
\hline proactive coping & 2.63 & .36 & 2.52 & .39 & 1.89 & 0.06 \\
\hline reflective coping & 2.75 & .39 & 2.81 & .46 & -0.94 & 0.35 \\
\hline
\end{tabular}




\begin{tabular}{|l|c|c|c|c|c|l|}
\hline strategic planning & 2.55 & .50 & 2.60 & .56 & -0.59 & 0.56 \\
\hline preventive coping & 2.75 & .36 & 2.77 & .48 & -0.26 & 0.80 \\
\hline instrumental support seeking & 2.58 & .43 & 2.44 & .48 & 2.06 & 0.04 \\
\hline emotional support seeking & 2.71 & .45 & 2.61 & .59 & 1.19 & 0.24 \\
\hline avoidant coping & 2.49 & .54 & 2.60 & .55 & -1.38 & 0.17 \\
\hline
\end{tabular}

Individuals in middle adulthood were most likely to use reflective and preventive coping (2.75) and less likely to use avoidant coping (2.49). Those in late adulthood were also most likely to use reflective coping (2.81) and least likely to seek out instrumental support (2.44). Significant differences between groups were found for seeking instrumental support and proactive coping (at the trend level). Both strategies scored higher in the middle adulthood group.

A method of analysis was adopted in which the typology included the entire group and then, in the analysis of types, the percentages of those in middle and late adulthood were given.

\subsection{Comparison of coping strategies and sociodemographic data in the identified} groups

Due to the fact that the results of the PCI subscales are obtained on scales with a different range (which makes their comparison impossible), the results were converted to a centile scale. A k-means cluster analysis was used to identify individuals differentiated by type of coping strategies. The table below shows the frequency of use of each coping strategy in each of the identified types (based on the final cluster centers). The extracted types were defined according to the specificity of the arrangement (profiles) of coping strategies:

Table 3. Separated types of coping according to the results of the standardized centile scale

\begin{tabular}{|l|c|c|c|c|}
\hline \multirow{2}{*}{ PCI scales } & \multicolumn{4}{c|}{ Type } \\
\cline { 2 - 5 } & $\begin{array}{c}1 \\
\mathrm{~N}=44\end{array}$ & $\begin{array}{c}2 \\
\mathrm{~N}=48\end{array}$ & $\begin{array}{c}3 \\
\mathrm{~N}=42\end{array}$ & $\begin{array}{c}4 \\
\mathrm{~N}=32\end{array}$ \\
\hline proactive coping & 25 & 73 & 60 & 42 \\
\hline reflective coping & 22 & 73 & 68 & 33 \\
\hline strategic planning & 31 & 77 & 55 & 32 \\
\hline preventive coping & 21 & 74 & 65 & 36 \\
\hline instrumental support seeking & 30 & 67 & 32 & 81 \\
\hline
\end{tabular}




\begin{tabular}{|l|c|c|c|c|}
\hline emotional support seeking & 28 & 73 & 34 & 71 \\
\hline avoidant coping & 56 & 53 & 56 & 32 \\
\hline
\end{tabular}

To give a more illustrative representation of the characteristics of each type, the following chart has been prepared:

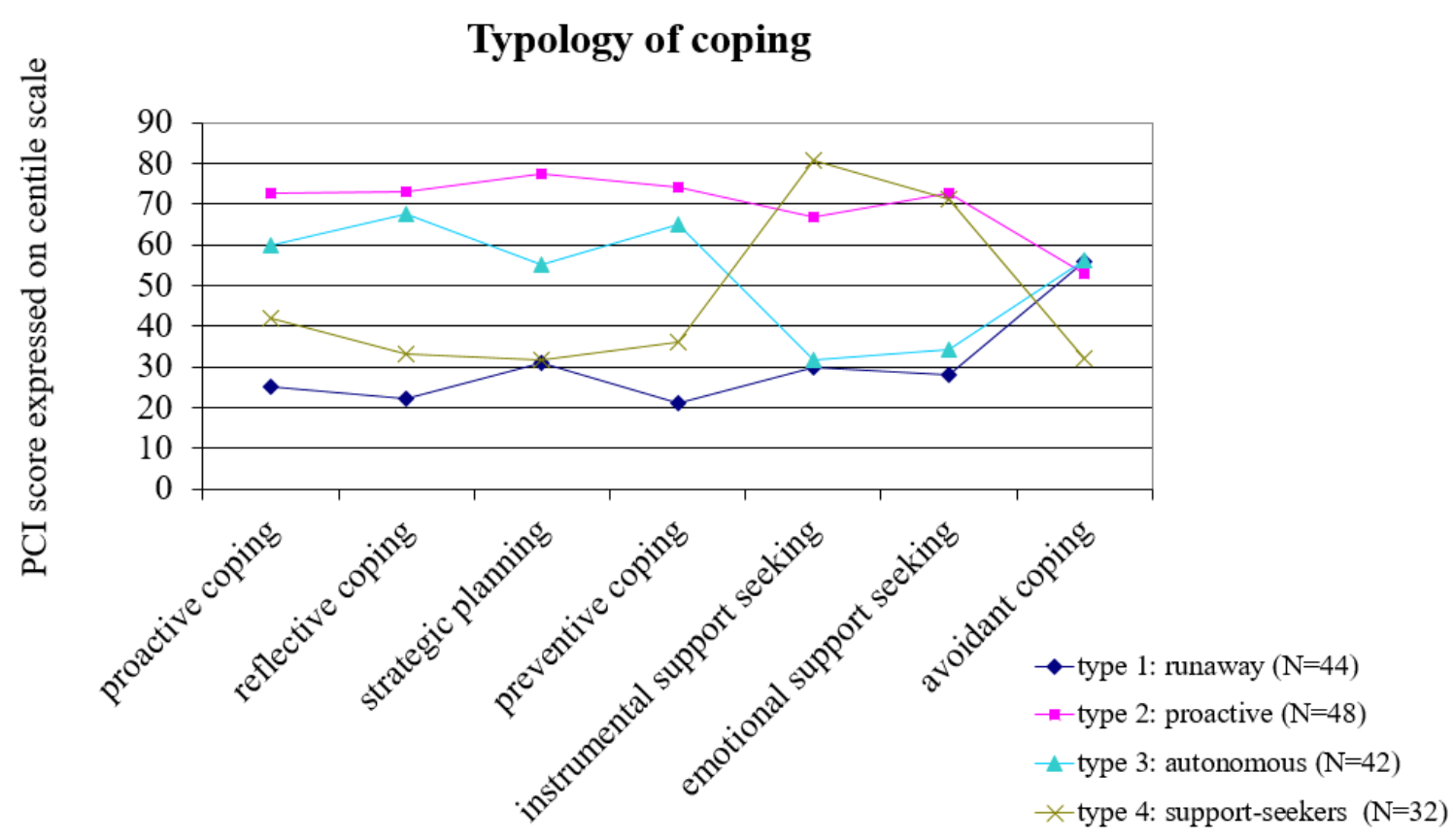

PCI coping strategies

Figure 1: Graphical representation of the identified types of coping

Type 1 (runaway) comprises people who make little use of adaptive coping strategies (21-28th percentile), and more often use avoidant strategies (56th percentile). These are mainly people in late adulthood $(61.4 \%)$, retired $(63.6 \%)$, with the highest percentage of people with vocational education (18\%) among the study groups.

Type 2 (proactive) includes people with a relatively high profile in the use of adaptive strategies (67-77th percentile), with a predominance of strategic planning (77th percentile) and with the highest level of use of proactive strategies (73rd percentile) among all types. The respondents classified in this group use an avoidance strategy to an average degree (53rd percentile). Type 2 includes almost equally people in middle $(52.1 \%)$ and late adulthood $(47.9 \%)$, equally working $(43.8 \%)$ and retired $(45.8 \%)$, with secondary education (43.8\%) or higher $(45.8 \%)$. 
Type 3 (autonomous) are people with a dominance of reflective (68th percentile), preventive (65th percentile) and proactive (60th percentile) coping, less likely to use instrumental and emotional support. Their level of avoidant strategies is similar to the previous types (56th percentile). This group consists mainly of people in late adulthood (59.5\%), with higher $(52.4 \%)$ or secondary $(42.9 \%)$ education.

Type 4 (support-seekers) are those predominantly seeking instrumental support (81 percentile), followed closely by emotional support (71 percentile). These individuals are least likely to seek strategic planning (32 percentile), reflective coping (33 percentile) and preventive coping (36th percentile). Similarly, they rarely use avoidance strategies (32nd percentile). This type is mainly found in middle adulthood (65.6\%), working (53.1\%), with higher education $(56.3 \%)$.

\subsection{Comparison of wisdom and resilience in the identified groups}

The identified types were compared with regard to the level of wisdom and resilience. An analysis of the variance was used for this purpose, and the results are presented in the table below.

Table 4. Comparison of wisdom and resilience in the identified types of coping

\begin{tabular}{|c|c|c|c|c|c|c|c|c|c|c|c|}
\hline \multirow{3}{*}{\multicolumn{2}{|c|}{ Variables }} & \multicolumn{8}{|c|}{ Types } & & \\
\hline & & \multicolumn{2}{|c|}{$\begin{array}{l}1(\mathrm{~N}=44) \\
\text { runaway }\end{array}$} & \multicolumn{2}{|c|}{$\begin{array}{l}2(\mathrm{~N}=48) \\
\text { proactive }\end{array}$} & \multicolumn{2}{|c|}{$\begin{array}{l}3(\mathrm{~N}=42) \\
\text { autonomous }\end{array}$} & \multicolumn{2}{|c|}{$\begin{array}{c}4(\mathrm{~N}=32) \\
\text { support-seekers }\end{array}$} & \multicolumn{2}{|c|}{ ANOVA } \\
\hline & & $\mathrm{M}$ & SD & $\mathrm{M}$ & $\mathrm{SD}$ & M & SD & M & SD & $\mathrm{F}$ & $\mathrm{p} \leq$ \\
\hline \multirow{5}{*}{$\sum_{\infty}^{\infty}$} & $\begin{array}{l}\text { Cognitive } \\
\text { dimension }\end{array}$ & 3.00 & 0.58 & 3.06 & 0.69 & 3.23 & 0.51 & 3.23 & 0.52 & 1.68 & 0.17 \\
\hline & $\begin{array}{l}\text { Affective } \\
\text { dimension }\end{array}$ & 3.24 & 0.54 & 3.48 & 0.47 & 3.40 & 0.51 & 3.49 & 0.51 & 2.16 & 0.09 \\
\hline & $\begin{array}{l}\text { Self-awareness } \\
\text { dimension }\end{array}$ & 2.95 & 0.63 & 3.08 & 0.82 & 3.23 & 0.70 & 3.22 & 0.67 & 1.45 & 0.23 \\
\hline & $\begin{array}{l}\text { Empathic } \\
\text { dimension }\end{array}$ & 3.54 & 0.65 & 4.04 & 0.63 & 3.92 & 0.62 & 3.64 & 0.66 & $5.88 \mathrm{a}, \mathrm{b}, \mathrm{e}$ & 0.001 \\
\hline & Overall score & 3.18 & 0.41 & 3.41 & 0.45 & 3.45 & 0.41 & 3.39 & 0.41 & $3.51 \mathrm{a}, \mathrm{b}$ & 0.02 \\
\hline \multicolumn{2}{|r|}{$\begin{array}{c}\text { Resilience - SPP-25 } \\
\text { (total score) }\end{array}$} & 62.70 & 11.76 & 77.35 & 11.40 & 72.02 & 12.63 & 64.94 & 9.56 & 14.91a,b,e,f & 0.001 \\
\hline
\end{tabular}

Assays for significant differences between groups based on Tukey's post hoc test: a: 1-2; b: 1-3 ; c: 1-4; d: 2-3; e: 2-4; f: 3-4 
Significant differences were noted between the types in the empathic wisdom dimension and in the total score. Type 2, the proactive one, has a significantly higher level of the empathic dimension and the overall score on this scale than type 1 (runaway), and a higher level of wisdom on the empathic dimension than type 4 (support-seekers). Also, both in the empathic dimension and in the overall score in the wisdom scale, the runaway type has a significantly lower level of this variable than type 3 (autonomous). Most differences between the types occur in terms of resilience. Type 1, the runaway group, has a lower level of this variable in relation to the proactive and autonomous types. On the other hand, the proactive type has the highest level of resilience (significantly higher than the runaway and supportseeking types). A significant difference in terms of this variable appears between type 3 and 4 . People classified as the autonomous type are more resilient than the support-seekers.

\section{Discussion}

The analysis of the profiles in each subtype allows us to describe the psychological characteristics of each. Type 1, called the runaway type, brings together individuals $(\mathrm{N}=44)$ for whom avoidant coping is the dominant strategy. These individuals refer with low frequency to the first six (in the PCI questionnaire) coping strategies, which can be described as mature and adaptive. Analyses show that these individuals are the least resilient. Also, the level of wisdom (overall score) is significantly lower in this group compared to type 2 (proactive) and lower in the empathic dimension compared to type 3 (autonomous). These individuals will therefore be more likely to delay taking remedial action in the face of danger and difficulty. Rather than seeing a challenge and opportunity for development in a crisis situation, they see only a threat. They may have difficulty building resources and setting life goals. They also lack the ability to anticipate and analyze problems. When confronted with problems, they are not able to plan their actions and take adequate steps to solve the stressful situation. They also miss the ability to seek help from others, either by seeking advice or emotional support. The runaway type is dominated by older and less educated people. This is consistent with previous research that has shown that older people in stressful situations, particularly interpersonal stress, are more likely to avoid threatening situations (Charles, Carstensen, \& McFall, 2001; Oberhauser, Neubauer, \& Kessler, 2017). A possible explanation for the overrepresentation of older adults in this type is a specific coping style in which, for individuals who lack extensive resources, the most effective and adaptive way to find themselves in a difficult situation is to simply avoid it (Birditt, Fingerman, 2005).

Type $2(\mathrm{~N}=48)$, defined as proactive, describes individuals who have the highest level of proactive coping in the group studied, as well as the best placed profile in the other beneficial strategies. These individuals are almost a mirror image of those classified as the runaway type. These individuals also score significantly higher in the resilience dimension 
than the runaway and support-seeking types. As for the wisdom level, the empathic dimension is significantly higher in the proactive type than in the runaway and support-seeking types. People in type 2 are able to autonomously set goals for themselves and achieve them. They treat the difficulties they encounter as challenges. This may be due to the lower neuroticism of individuals who prefer proactive coping strategies (Straud, McNaughton-Cassill, Fuhrman 2015). Individuals in this subtype not only anticipate upcoming difficulties, but by being concerned about building resources, they seek to be ready for any potential stressors. The proactive type therefore describes individuals who are able to anticipate and consider different scenarios for the course of a difficult situation. They are also able to call on the help and support of others, as well as provide support themselves. What is important in describing this group is that it is equally composed of people in middle and late adulthood, living in rural and urban areas, working and retired, and with secondary and higher education. This may mean that a proactive approach to stress is in its own way universal and independent of age. This is supported by the results of a study that was carried out by Ouwehand, Ridder, Bensing (2008). People in middle and late adulthood showed similar levels of proactive strategies. A study in which Neubauer, Smyth, and Sliwinski (2019) found that older adults showed higher levels of proactive coping compared to those in middle adulthood yielded different results. The discrepancies may be due to the different research methodologies and definitions of proactivity. This may indicate the validity of the approach proposed in the current study reported in this paper, which allows for a profiling, and therefore more descriptive, account of proactivity. This is supported by a study by Tovel and Carmel (2014), which showed that proactive coping patterns are a factor supporting healthy aging, but only patterns related to specific planning, not to decision-making based on personal preferences.

Type 3, which can be described as autonomous, comprises people $(\mathrm{N}=42)$ with medium to higher levels of reflective, preventive and proactive coping. They are also less likely to have used instrumental and emotional support. In contrast, their level of avoidant coping is similar to previous types. These people also have a higher level of wisdom in the overall and empathic factor and greater resilience than the runaway type. Individuals in the autonomous type, like those in the proactive type, are able to set goals and achieve them, anticipate different ways to solve a problem and be ready for upcoming difficulties. However, they have difficulty in seeking support from others. This cannot be explained by reluctance or a tendency to avoid people, because in the empathic wisdom dimension, which describes a positive and caring reference to others, these individuals do not differ from the other groups. It seems, therefore, that these individuals are self-reliant, independent and willing to face problems alone. This assumption is supported by the fact that this type has the highest percentage of people with higher education compared to the other types. Given that this group is dominated by people in late adulthood, it may also be suggested that the 
reliance in coping with stress is mainly due to the lower availability of others in the environment (cf. Galiana, Tomás, Fernández, Oliver, 2020).

Type $4(\mathrm{~N}=32)$, was defined as the support-seekers. The profile of this type matches people in whom two strategies dominate - seeking instrumental and emotional support. The other scales are significantly lower (around the 30th percentile) and only proactive coping is close to the average results (42nd percentile). These individuals have a lower level of wisdom in the empathic dimension than those in the proactive type. This may indicate a lower ability to take another person's perspective, hence these individuals may overburden others with their expectation of support and care. The analyses also showed that resilience in individuals in the support-seeking type is significantly lower than those in the autonomous type. This may suggest that they are less autonomous in coping with adversity and more dependent on the help and support of others. Given that this type includes mainly people in middle adulthood, working, with higher education, it can be deduced that these individuals are well socialized and therefore able to cope through an extensive support network. The result regarding the lower representation of older people in this type may be related to better emotional regulation among the elderly (Berg, Upchurch, 2007; Lantrip, Huang, 2017). This feature may allow them to be less dependent on the emotional support of others. Older adults in their coping processes may also rely more on their accumulated resources, thus do not require as much support as those in middle adulthood (cf. Baltes, Lindenberger, Staudinger, 2006).

A similar procedure of distinguishing types of coping on the basis of PCI was performed by Brzezinska (2011, p. 159). In her study on proactivity in older people, she managed to identify 4 types of coping varying according to the frequency of use of particular strategies. When comparing the two typologies, similarities can be found between the passive and runaway, active and proactive, optimistic and autonomous, and defensive and support-seeking types. This clearly shows that the coping styles examined with the PCI take the form of relatively stable coping styles within the population.

The results obtained in the present study are consistent with the results obtained by Ardelt (2005, cf. Ardelt, Jeste, 2018), where wise people used strategies such as mental distancing, active coping (by reformulating the problem and taking control of the situation) and applying knowledge acquired in the course of life. Also in the studies reported in this paper, individuals classified into types characterized by an advantageous coping strategy profile were found to be simultaneously more wise and resilient than those with a less adaptive and more reactive coping profile. Individuals with high levels of wisdom in the empathic dimension are less self-centered and thus able to understand others better and, as seems a natural consequence, to act (Ardelt, 2003).

Resilience emerged as a significant differentiating factor between different types of coping with stress. Although it is still debated in the literature whether resilience should be 
seen in terms of a process or a trait, resilience is nevertheless seen as the positive psychological fruit of coping despite experiencing something that could potentially lead to serious negative consequences (Aldwin, Yancura, Lee, 2021, pp. 288-291). Resilience is also a kind of plasticity that affects the ability to recover and achieve balance after difficult psychosocial experiences (Choowattanapakorn et al., 2010, p. 329; Zapater-Fajarí, CrespoSanmiguel, Pulopulos, Hidalgo, \& Salvador, 2021).

To summarize, it is important to note that consistent profiles of the use of coping strategies can be distinguished in middle and late adulthood. The types identified differ in terms of resilience and wisdom. Both wisdom, understood as a structure consisting of a cognitive, reflective and affective component, and resilience being a personality trait predisposed to a more proactive, goal-oriented attitude. A better understanding of the resources of individuals presenting different coping profiles in middle and late adulthood may be helpful in understanding the relatively stable levels of coping across the lifespan (cf. Aldwin, Choun, Lee, Brockmann, \& Spiro, 2019).

\section{Bibliography:}

Aldwin, C.M., \& Levenson, M.R. (2019). The practical applications of self-transcendent wisdom, (in:) R. Sternberg, H.C. Nusbaum, \& J. Glück (eds.), Applying wisdom to contemporary world problems, 293-307, New York: Springer Nature.

Aldwin, C.M., Choun, S., Lee, H., Brockmann, A., Spiro A. III (2019). Patterns of coping trajectories: Longitudinal Findings from the VA Normative Aging Study. Paper presented at the Annual Meetings of the American Psychological Association, Chicago.

Aldwin, C.M., Choun, S., Spiro, A. III (2017). Does coping change with age? Longitudinal findings from the VA Normative Aging Study. Poster presented at the Annual Meetings of the American Psychological Association, Washington, D.C.

Aldwin, C.M., Igarashi, H., Levenson, M.R. (2019). Wisdom as self-transcendence, (in:) R.J. Sternberg, \& J. Glück (eds.), The Cambridge handbook of wisdom, 122-143, New York: Cambridge University Press, https:/ / doi.org/10.1017/9781108568272.007.

Aldwin, C.M., Yancura, L., Lee, H. (2021). Chapter 17 - Stress, coping, and aging, (in:) K.W.Schaie, S.L. Willis (eds.), Handbook of the Psychology of Aging, 275-286, Cambridge: Academic Press.

Ardelt, M. (2003). Empirical assessment of a three-dimensional wisdom scale, Research on Aging, 25(3), 275-324, https://doi.org/10.1177/01640275030250030.

Ardelt, M. (2005). How Wise People Cope with Crises and Obstacles in Life, Revision: A Journal of Consciousness and Transformation, 28, 7-19, https:// doi.org/10.3200/REVN.28.1.7-19. 
Ardelt, M. (2016). Disentangling the relations between wisdom and different types of wellbeing in old age: Findings from a short-term longitudinal study, Journal of Happiness Studies: An Interdisciplinary Forum on Subjective Well-Being, 17(5), 1963-1984, https:// doi.org/10.1007/s10902-015-9680-2.

Ardelt, M., Jeste, D.V. (2018). Wisdom and Hard Times: The Ameliorating Effect of Wisdom on the Negative Association Between Adverse Life Events and Well-Being, The journals of gerontology. Series B, Psychological sciences and social sciences, 73 (8), 13741383, https://doi.org/10.1093/geronb/gbw137.

Ardelt, M., Pridgen, S., \& Nutter-Pridgen, K.L. (2018). The relation between age and threedimensional wisdom: Variations by wisdom dimensions and education, The Journals of Gerontology: Series B: Psychological Sciences and Social Sciences, 73 (8), 1339-1349, https:// doi.org/10.1093/geronb/gbx182.

Aspinwall, L.G., Taylor, S.E. (1997). A stitch in time: Self-regulation and proactive coping, Psychological Bulletin, 121(3), 417-436, https:/ / doi.org/10.1037/0033-2909.121.3.417.

Baltes, P.B., Lindenberger, U., Staudinger, U.M. (2006). Life Span Theory in Developmental Psychology (in:) R.M. Lerner \& W. Damon (eds.), Handbook of child psychology: Theoretical models of human development, (569-664), New York: John Wiley \& Sons Inc.

Beehr, T.A., McGrath, J.E. (1996). The methodology of research on coping: Conceptual, strategic, and operational-level issues, (in:) M. Zeidner, N.S. Endler (eds.), Handbook of coping - theory, research, applications, 5-82, New York: Wiley.

Berg, C.A., \& Upchurch, R. (2007). A developmental-contextual model of couples coping with chronic illness across the adult life span, Psychological Bulletin, 133 (6), 920-954, https:// doi.org/10.1037/0033-2909.133.6.920.

Bernat, A., Krzyszkowska, M. (2017). Znaczenie i sposoby wykorzystania psychospołecznych zasobów zaradczych w ujęciu S.E. Hobfolla. Studia Paradyskie, 27, 255-278.

Birditt, K.S., Fingerman, K.L. (2005). Do we get better at picking our battles? Age group differences in descriptions of behavioral reactions to interpersonal tensions, The Journals of Gerontology, Series B: Psychological Sciences and Social Sciences, 60, 121-128, https:// doi.org/10.1093/geronb/60.3.P121.

Blanco-Molina, M., Pinazo-Hernandis, S., Montoro-Rodriguez, J., \& Tomas, J.M. (2021). Testing a Proactive Model of Successful Aging Among Older Adults in Costa Rica and Spain, The International Journal of Aging and Human Development, 93 (1), 619-635, https:// doi.org/10.1177/0091415020974621.

Brennan, P.L., Holland, J.M., Schutte, K.K., \& Moos, R.H. (2012). Coping trajectories in later life: A 20-year predictive study, Aging $\mathcal{E}$ Mental Health, 16 (3), 305-316, https:// doi.org/10.1080/13607863.2011.628975.

Brzezińska, M. (2011). Proaktywna starość. Strategie radzenia sobie ze stresem w okresie późnej dorostości. Warszawa: Difin. 
Campbell-Sills, L., Cohan, S.L., Stein, M.B. (2006). Relationship of resilience to personality, coping, and psychiatric symptoms in young adults, Behaviour Research and Therapy, 44, 585-599, https:// doi.org/10.1016/j.brat.2005.05.001.

Chanduszko-Salska, J., Ogińska-Bulik, N. (2011). Prężność a ryzyko uzależnienia od jedzenia, (in:) L. Golińska, E. Bielawska-Batorowicz (eds.), Rodzina i praca w warunkach kryzysu, 399-410, Łódź: Wydawnictwo Uniwersytetu Łódzkiego.

Charles, S.T., Carstensen, L.L., \& McFall, R.M. (2001). Problem-solving in the nursing home environment: Age and experience differences in emotional reactions and responses, Journal of Clinical Geropsychology, 7, 319-330, https:// doi.org/10.1023/A:1011352326374.

Chen, Y., Peng, Y., Xu, H., \& O'Brien, W.H. (2018). Age Differences in Stress and Coping: Problem-Focused Strategies Mediate the Relationship Between Age and Positive Affect, International Journal of Aging \& Human Development, 86 (4), 347-363, https:// doi.org/10.1177/0091415017720890.

Choowattanapakorn, T., Alex, L., Lundman, B., Norberg, A., Nygren, B. (2010). Resilience among women and men aged 60 years and over in Sweden and in Thailand, Nursing $\mathcal{E}$ Health Sciences, 12, 329-335, https:// doi.org/10.1111/j.1442- 2018.2010.00534.x.

Chwaszcz, J., Bartczuk, R.P., Niewiadomska, I., Hobfoll, S.E., \& Palacz-Chrisidis, A. (2020). The Polish Adaptation of the Strategic Approach to Coping Scale, Annals of Psychology, 23(1), 23-43, https:// doi.org/10.18290/rpsych20231-2.

Clayton, V.P., Birren, J.E. (1980). The development of wisdom across the life-span: A reexamination of an ancient topic, (in:) P.B. Baltes and O.G. Brim, Jr. (eds.), Life-span development and behaviour, 103-135, New York: Academic Press.

Diehl, M., Chui, H., Hay, E.L., Lumley, M.A., Grühn, D., Labouvie-Vief, G. (2014). Change in coping and defense mechanisms across adulthood: Longitudinal findings in a European American sample, Developmental Psychology, 50 (2), 634-648, https:// doi.org/doi:10.1037/a0033619.

Drwal R. (1995). Adaptacja kwestionariuszy osobowości: wybrane zagadnienia i techniki, Warszawa: PWN.

Felcyn-Koczewska, M., Ogińska-Bulik, N. (2011). Rola prężności w rozwoju potraumatycznym osób w żałobie (in:) L. Golińska, E. Bielawska-Batorowicz (eds.), Rodzina i praca w warunkach kryzysu, 511-524, Łódź: Wydawnictwo Uniwersytetu Łódzkiego.

Fontes, A.P., Neri, A.L. (2015). Resilience in aging: literature review, Ciência E Saúde Coletiva, 20(5), 1475-1495, https:/ / doi.org/10.1590/1413-81232015205.00502014.

Fritzson, A., Lieberman, M., \& Tugade, M.M. (2017). Assessment of mood: Examining links between emotions and health, (in:) C. Llewellyn et al. (eds.), Cambridge Handbook of Psychology, Health, and Medicine, New York: Cambridge University Press. 
Galiana, L., Tomás, J.M., Fernández, I., \& Oliver, A. (2020). Predicting Well-Being Among the Elderly: The Role of Coping Strategies, Frontiers in Psychology, https:// doi.org/10.3389/fpsyg.2020.00616.

Gamrowska, A., Gałkowska-Bachanek, M. (2014). Aktywność zaradcza a postawy wobec własnej starości, [Active coping attitudes toward aging in the elderly], Polskie Forum Psychologiczne, 19 (4), 505-521, https:// doi.org/10.14656/PFP20140406.

Gamrowska, A., Steuden, S. (2014). Coping with the events of daily life and quality of life of the socially active elderly, Health Psychology Report, 2(2) 123-131, https:// doi.org/10.5114/hpr.2014.43919.

Greenglass, E. (2002). Chapter 3. Proactive coping, (in:) E. Frydenberg (eds.), Beyond coping: Meeting goals, vision, and challenges, 37-62, London: Oxford University Press.

Greenglass, E.R., Fiksenbaum, L. (2009). Proactive coping, positive affect, and well-being: testing for mediation using path analysis, European Psychologist, 14(1), 29-39, https:// doi.org/10.1027/1016-9040.14.1.29.

Greenglass, E., Schwarzer, R., Jakubiec, S. D., Fiksenbaum L., Taubert, S. (2014). The Proactive Coping Inventory (PCI): a multidimensional research instrument. Paper presented at the 20th International Conference of the STAR (Stress and Anxiety Research Society) Cracow, Poland, July 12-14.

Gulbrandsen, C. (2016). Measuring older women's resilience: Evaluating the suitability of the Connor-Davidson Resilience Scale and the Resilience Scale, Journal of Women $\mathcal{E}$ Aging, 28(3), 225-237, https:// doi.org/10.1080/08952841.2014.951200.

Hamarat, E., Thompson, D., Steele, D., Matheny, K., Simons, C. (2002) Age Differences in Coping Resources and Satisfaction With Life Among Middle-Aged, Young-Old, and Oldest-Old Adults, The Journal of Genetic Psychology, 163(3), 360-367, https:// doi.org/10.1080/00221320209598689.

Jeste, D.V., Savla, G.N., Thompson, W.K., Vahia, I.V., Glorioso, D.K., Martin, A.S., Palmer, B.W., Rock, D., Golshan, S., Kraemer, H.C., \& Depp, C.A. (2013). Association between older age and more successful aging: critical role of resilience and depression, The American Journal of Psychiatry, 170(2), 188-196, https:// doi.org/10.1176/appi.ajp.2012.12030386.

Lantrip, C.M., Huang, J.H. (2017). Cognitive Control of Emotion in Older Adults: A Review, Clinical Psychiatry, 3(1), 1-10, https://doi.org/10.21767/2471-9854.100040.

Li, W.W., \& Miller, D.J. (2017). The impact of coping and resilience on anxiety among older Australians, Australian Journal of Psychology, 69, 263-272, https:// doi.org/10.1111/ajpy.12152.

MacLeod, S., Musich, S., Hawkins, K., Alsgaard, K., Wicker, E.R. (2016). The impact of resilience among older adults, Geriatric Nursing, 37(4), 266-272, https:// doi.org/10.1016/j.gerinurse.2016.02.014. 
Morano, C. (2010). Resilience and Coping with Trauma: Does Gender make a Difference? Journal of Human Behavior in the Social Environment, 20, 553-368, https:// doi.org/10.1080/10911350903275358.

Neubauer, A.B., Smyth, J.M., Sliwinski, M.J. (2019). Age Differences in Proactive Coping With Minor Hassles in Daily Life, The Journals of Gerontology: Series B, 74(1), 7-16. https:// doi.org/10.1093/geronb/gby061.

Noone, P. (2017). The Holmes-Rahe Stress Inventory, Occupational Medicine, 67 (7), 581-582, https:// doi.org/10.1093/occmed/kqx099.

Oberhauser, L., Neubauer, A.B., \& Kessler, E.-M. (2017). Conflict avoidance in old age: The role of anticipated loneliness, GeroPsych: The Journal of Gerontopsychology and Geriatric Psychiatry, 30(2), 61-70, https:// doi.org/10.1024/1662-9647/a000168.

Ogińska-Bulik, N. (2009). Osobowość typu D. Teoria i badania, Łódź: Wydawnictwo WSHE.

Ogińska-Bulik, N. (2011). Rola prężności w zapobieganiu negatywnym skutkom stresu zawodowego. (in:) L. Golińska, E. Bielawska-Batorowicz (eds.), Rodzina i praca w warunkach kryzysu, 485-498, Łódź: Wydawnictwo Uniwersytetu Łódzkiego.

Ogińska-Bulik, N., Juczyński, Z. (2008). Skala Pomiaru Prężności (SPP-25), Nowiny Psychologiczne, 3, 39-56.

Ogińska-Bulik, N., Juczyński, Z. (2011). Prężność u dzieci i młodzieży: charakterystyka i pomiar - Polska Skala SPP-18, Polskie Forum Psychologiczne, 16 (1), 7-28.

Ouwehand, C., de Ridder, D.T.D., \& Bensing, J.M. (2008). Individual differences in the use of proactive coping strategies by middle-aged and older adults, Personality and Individual Differences, 45, 28-33, https:// doi.org/10.1016/j.paid.2008.02.013.

Pasikowski, T., Sęk, H., Greenglass, E., Taubert, S. (2002). The proactive coping inventory Polish adaptation, Polish Psychological Buletin, 33, 41-46.

Reuter, T., Schwarzer, R. (2015). Manage Stress at Work through Preventive and Proactive Coping, (in:) E.A. Locke (ed.), Handbook of Principles of Organizational Behavior, 499515, New York: John Wiley \& Sons, https:// doi.org/10.1002/9781119206422.ch27.

Ribeiro, M. dos S., Borges, M. da S., Araújo, T.C.C.F. de, \& Souza, M.C. dos S. (2017). Coping strategies used by the elderly regarding aging and death: an integrative review, Revista Brasileira de Geriatria e Gerontologia, 20 (6), 869-877, https:// doi.org/10.1590/1981-22562017020.170083.

Schwarzer, R. (2000). Manage stress at work through preventive and proactive coping. (in:) E.A. Locke (eds.), The Blackwell handbook of principles of organizational behaviour, 342355, Oxford: Blackwell.

Schwarzer, R., Taubert, S. (2002). Tenacious goal pursuits and striving toward personal growth: Proactive coping. (in:) E. Frydenberg (ed.), Beyond coping: Meeting goals, visions and challenges, 19-35, London: Oxford University Press, https://doi.org/10.1093/med:psych/9780198508144.003.0002. 
Sęk, H., Pasikowski, T. Taubert, S., Greenglass, E., Schwarzer, R. (2002). Kwestionariusz Reakcji na Codzienne Wydarzenia [The Proactive Coping Inventory (PCI): Polish Version], from: http://userpage.fu-berlin.de/ health/pol_pci.htm, (access: 05.09.2021).

Steuden, S. (2017). Psychologia starzenia się i starości, Warszawa: PWN.

Steuden, S., Brudek, P., Izdebski, P. (2016). Polish Adaptation of Monika Ardelt's ThreeDimensional Wisdom Scale (3D-WS), Annals of Psychology, 4(19), 767-789, https:// doi.org/10.18290/RPSYCH.2016.19.4-4EN.

Straud, C., McNaughton-Cassill, M., \& Fuhrman, R. (2015). The role of the Five Factor Model of personality with proactive coping and preventive coping among college students.

Personality and Individual Differences, 83, 60-

64,https:// doi.org/10.1016/j.paid.2015.03.055.

Thomas, M.L., Bangen, K.J., Ardelt, M., Jeste, D.V. (2017). Development of a 12-item abbreviated Three-Dimensional Wisdom Scale (3D-WS-12): Item selection and psychometric properties, Assessment, 24, 71-82.

Tovel, H., \& Carmel, S. (2014). Maintaining successful aging: The role of coping patterns and resources, Journal of Happiness Studies: An Interdisciplinary Forum on Subjective WellBeing, 15 (2), 255-270, https:/ / doi.org/10.1007/ s10902-013-9420-4.

Tugade, M.M., Devlin, H.C., \& Fredrickson, B.L. (2014). Infusing positive emotions into life: The broaden-and- build theory and a dual-process model of resilience, (in:) M.M. Tugade, M.N. Shiota, \& L.D. Kirby (eds.), Handbook of Positive Emotions, New York: Guilford Press.

Vitorino, L.M., Low, G., \& Vianna, L.A.C. (2016). Linking Spiritual and Religious Coping With the Quality of Life of Community-Dwelling Older Adults and Nursing Home Residents, Gerontology and Geriatric Medicine, 2, 1-9, https:// doi.org/10.1177/2333721416658140.

Wu, Y., Yu, W., Wu, X., Wan, H., Wang, Y., \& Lu, G. (2020). Psychological resilience and positive coping styles among Chinese undergraduate students: a cross-sectional study, BMC Psychology, 8 (1), 1-11, https:/ / doi.org/10.1186/ s40359-020-00444-y.

Yang, S.-Y. (2008). A process view of wisdom, Journal of Adult Development, 15 (2), 62-75, http://doi.org/10.1007/s10804-008-9037-8.

Zapater-Fajarí, M., Crespo-Sanmiguel, I., Pulopulos, M., Hidalgo, V., Salvador, A. (2021). Resilience and Psychobiological Response to Stress in Older People: The Mediating Role of Coping Strategies, Frontiers in Aging Neuroscience, 13, http://doi.org/10.3389/fnagi.2021.632141.

Zhou, G., Gan, Y., Knoll, N., \& Schwarzer, R. (2013). Proactive coping moderates the dietary intention-planning-behavior path, Appetite, 70, 127-133, http://doi.org/10.1016/j.appet.2013.06.097. 
